\title{
Territory and ontology in the educational practices of an indigenous Zapotecan community in Mexico
}

\author{
Raquel Aparicio Cid, Universidad Veracruzana, Mexico
}

\begin{abstract}
This paper is inscribed within the study of social educational practices in rural indigenous communities of Mesoamerica, practices through which the store of knowledge that guides relationships with the environment are recreated. Ethnographical research conducted in a Zapotec community in the state of Oaxaca, southern Mexico, shows that communitarian educational practices form an everyday cognitiveaxiological framework through which the norms of coexistence and social organisation are assimilated. The underlying purpose of these practices is to promote the historical and cultural continuity of the collective based on a reciprocal relationship with the environment, which is their home and the source of their well-being and biocultural identity. The resilience of this population lies in their use of socio-historical learning to renew their organisational structures, with the purpose of facing the challenges posed by civilisation. This paper describes aspects of these historical learnings and current social educational practices, as well as their ontological principles.
\end{abstract}

Keywords: indigenous communities, communitarian education, communality, nature.

\section{Resumen}

El artículo se inscribe en el estudio de las prácticas formativas comunitarias en poblaciones rurales indígenas de Mesoamérica, a través de las cuales se recrean los acervos de conocimientos que orientan las relaciones de esos grupos con sus territorios. Una investigación etnográfica realizada en una comunidad zapoteca del estado de Oaxaca, al sur de México, muestra que la educación comunitaria conforma un entramado cognitivo-axiológico cotidiano a través del cual se asimilan las normas de convivencia y de organización social. La intención ulterior de esta formación es propiciar la continuidad histórica y cultural del colectivo a partir de una relación recíproca con el territorio, que es su hogar, fuente de bienestar y de su identidad biocultural. La capacidad de adaptación de esta población se explica en el aprovechamiento de los aprendizajes sociohistóricos para renovar sus estructuras organizativas, con el fin de enfrentar los retos que le plantea el devenir civilizatorio. En este texto se describen algunos aspectos de esos aprendizajes históricos y de las prácticas educativas sociales, así como de sus principios ontológicos.

Palabras clave: comunidades indígenas, educación comunitaria, comunalidad, naturaleza. 


\section{Introduction}

In the midst of the prevailing civilisational crisis, the epistemic practices of traditional societies are attracting growing interest from the social and natural sciences because of these societies' capacity for generating knowledge that 1 ) responds to unprecedented situations in their social lives and in their relationship with the environment, and 2) enables them to develop a significant level of adaptability to internal and external changes.

Indigenous, local, or traditional knowledge systems are inscribed in what Rengifo (2015) calls 'other knowledge': that is, knowledge systems based on cognitive and cultural premises that correspond to a type of knowledge and epistemic-ontological perspectives that are different to modern thinking. It refers to knowledge that has been constructed, preserved and used by communities and traditional people such as the indigenous groups of Latin America, knowledge which shapes the heart of these cultures and 'has an enormous potential for the understanding and solving of different social and environmental problems' (Olivé, 2009:21). In the specific case of Mexican indigenous peoples' knowledge systems, Boege (2008) and Toledo and BarreraBassols (2008) consider such systems as a reference for the creation of new models of society better able to deal with the current civilisational crisis.

This knowledge is intrinsically bound to practices centred around administering local ecosystems to meet livelihood needs (Toledo \& Barrera-Bassols, 2008) and is the result of lengthy interactions between communities and their environment. It arises from individual and social experiences developed in a context of continuous change (Barrera-Bassols, 2003), which, when imprinted in concrete processes of social interaction, develops its own pedagogies (Chamoux, 1992; Gómez, 2003; Nahmad, 1988) through which knowledge is inherited in a trans-generational way (Toledo \& Barrera-Bassols, 2008). This suggests that communitarian educational practices are critical for understanding the ontological foundations of the relationships traditional societies have with their environment, as it is through these practices that the meaning of nature and the environment is developed in congruence with the culture and the collective project of life.

From this argument arises the relevance of cultural diversity for the planet's future. Assuming 1) that culture is the mechanism through which human beings interact with their environment (Ángel-Maya, 2003); 2) that the global socio-environmental crisis is a consequence of a monocultural society (Quijano, 2000) and of a predator lifestyle pushed by western civilisation (Mignolo, 2014); and 3) that cultural and epistemic diversity emerge as indispensable for facing the problems of civilisation, it is then possible to say that human survival may ultimately rely on cultural diversity (Milton, 1997; Toledo, Alarcón-Chaires, Moguel, Olivo, Cabrera, Leyequien \& Rodríguez-Aldabe, 2002). ${ }^{1}$

This paper presents the results of research focused on the study of certain communitarian educational practices that retain the historical-cultural continuity of an indigenous population's relationship with their natural environment within a scenario of the changes propagated by diverse mechanisms of the world-system (Quijano, 2000). ${ }^{2}$

One of the objectives of this study is to identify the epistemic elements and ontological principles of said practices, with the aim of enriching the theoretical-practical framework 
of environmental education for sustainability. ${ }^{3}$ For such a purpose, the selected community presents a relevant profile because its members acknowledge a process of productive transition as a necessary life-changing project and, despite this, their educational social schemes continue to reproduce the values and elements of an ancestral culture, one that is closely connected to its relationship with the environment and to the principle of communality in all its collective relations. ${ }^{4}$ This study was rooted in the assumption that, even in changing processes and similar social challenges, this type of social education can constitute a tool for the transformation of those civilisational paradigms that are placing global ecosystems at risk.

La Trinidad Ixtlán is located in the region known as the Sierra Norte in the municipality of Xiacui, Oaxaca, southern Mexico. This agrarian nucleus encompasses 805 hectares of temperate forest, 704 of which are under communal land ownership and forest management. Commercial forest management represents an important source of income and social benefit for the population.

The community, with 783 inhabitants, is governed by an indigenous normative system which informs their administrative-political organisation. The supreme governing body in this system is the General Assembly of Comuneros (community land co-proprietors), which is responsible for discussing problems and making decisions on issues related to social organisation and to managing the environment.

\section{Methodological approach}

This qualitative research was undertaken as an ethnographic profile through an immersion in the community. Data gathering was carried out via the active observation of, and interviews conducted with, diverse community actors. Observation was centred progressively on three aspects: the actors' daily activities; the verbal expressions generated during the activities; and the communicative interactions that the researcher held with several interlocutors. Since 'verbal action is, merely, another form of social action' (Díaz de Rada, 2011:50), the material obtained was considered ethnographic, as it involved extended processes of communication and cultural reproduction. Taking the records of the field journal as a base, and as a result of an ethnographic analytical procedure, observation tables were developed to record specific communitarian educational practices.

In addition to holding informal conversations with several community actors, 14 interviews were conducted with people whose activities are directly related to the land, mainly in agriculture and forestry. Three of the interviewees were women and eight were men, with ages ranging from 40 to 82 years. These interviews were structured so as to identify, from the interviewers' perspective, the community's most significant historical events that come into play in their current social behaviour and collective understanding of their environment. In turn, the main analytical categories emanating from the observations were consolidated with a content analysis of the interviews. The set of results arising from both procedures form the basis of the theoretic-epistemic reflection that made it possible to infer 1) the components of the communitarian educational practices and 2) the historical and personal learnings influencing the social construction of contemporary notions regarding community life and the natural environment. This work is detailed below. 


\section{Identification of communitarian educational practices}

The communitarian pedagogical practices were studied in family life and in productive work scenarios, as well as in the context of communitarian daily life where these were made evident. Some of the interactions that show the effects of social education are: the observance of public order; actions and discussions on social organisation - particularly issues related to the General Assembly of Comuneros; forest enterprises; the performance of the authorities; and conversations on social, political, historical, cultural, productive and environmental events.

Ornelas (2007) points out that, from a broader perspective, educational practice is omnipresent in all kinds of human interaction, it overcomes intentionality and systematicity, and addresses not only the present or daily life but also socio-cultural and historical processes. This idea guides the view of social phenomenon as a permanent educational process whose learnings are cumulative and, at the same time, continuously recreated. This poses a methodological challenge: if the educational practice 'implies teaching-learning processes are intrinsic to the different ambits of personal interaction' (Ornelas, 2007:89) and if, in a context like the one studied, almost every social practice can shape an educational practice, how is it possible to define what exactly is educational in community interactions?

A conceptual formulation of the social educational practices was first determined through conversations held with certain comuneros, then complemented with relevant theoretical sources that enabled the setting of a basic model for recording and analysing the social educative schemes described. The information from the empirical and theoretical sources was systemised and summarised in a table template that enabled the organisation of the data obtained from interviews as well as the recording of the observations on certain social organisational practices and the factors shaping them from an educational perspective. Such factors are: the object of knowledge or content; the methods, processes or techniques for teaching-learning; the environment as a learning or educative space; the temporal context (either the actual moment of the educational practice or the historical moment, or both); the tools, instruments and resources, either material or symbolic; the practice's level of institutionalisation; and an evaluation of the learnings.

As a result of this systematisation and analysis, the characteristics of the four central schemes within the social educative group were identified: the historical learning related to the environment; external technical capacities; educative community practices for cultural and communitarian continuity; and the family educative schemes for the subsistence and biological reproduction of the group.

This conceptual formulation was presented to three senior citizens in the community for the purpose of discussing the formulation's relevance and validity. This feedback led to the finding that external training is currently no longer relevant since it has fulfilled the purpose for which it was required, and so it was decided to integrate it as part of the socio-historical learnings. It was also found that the educative family schemes for subsistence do not represent a widespread educational social practice as a result of the gradual abandonment of these primary activities at home. Nevertheless, within family education practices, families do not in fact ignore the enforcement of community values related to their environment and community life; what 
prevents the functioning of this axiological construction is the individual's physical detachment from the land. Conversely, in the case of farmers and forestry workers, the relationship with the land is close and constant, fostered as it is by work.

In this manner, and in contrast with several indigenous and farmer communities in the country where the family structure for subsistence is paramount, the social educational schemes for cultural and community continuation in La Trinidad Ixtlán remain very influential thanks to their absorption-reproduction through community organisation, collective practices, shared values and individuals' behaviour. Such schemes have incorporated socio-historical learnings and have as their goal cultural, social and biological continuation, which emanates from the basis of their lives, namely their communal territory.

The following sections describe the historical learnings related to the environment and a specific communitarian educative scheme based on those lessons. They describe the way learnings were incorporated into the store of communitarian knowledge and how they define the current community-territory relationship.

\section{Socio-historical learnings: The strength of the community}

During the 20th century, La Trinidad Ixtlán was affected by several historical events, two of them of particular significance: the legal dispute on territorial boundaries between neighbouring villages in the 1940s and, in the 1950s, the imposition of government concessions that barred them from administering their forests for a long period. ${ }^{5}$ In both cases, and because of their vast historical and cultural richness and their significance for the well-being of the community, the population deployed several strategies to recover the ownership and management of their lands. These events generated critical conditions for action and created a favourable situation for the deployment of several cognitive and cultural factors as well as for the generation of new learnings related to the management of their territory. ${ }^{6}$

Concerning the forest concessions, the community actively sought specialised technical and legal advice to deal with the problem, enlisting assistance from a group of engineers and professionals, who trained several dozen comuneros. This relationship led to knowledge transfer and to the development of skills on exogenous topics, which were all swiftly adopted. In addition to this knowledge, the process represented a profound social learning that to this day affects productive practices and the people's view of their environment within their perception of time. $^{7}$

As in the past (and this constitutes the recursivity of the processes of social knowledge production), such learnings - reproduced by the people who have lived through those events, today most of them senior people - have a direct moral incidence in collective behaviour towards the environment (conservation and sustainable management) and are based on the community's awareness of their dependence on the environment for their welfare. A carpenter from the community says the following:

We depend a lot on the forest and that is why we have the idea that we must take care of it. Right now we are the ones benefiting from what our ancestors accomplished. And we are doing 
the same thing, managing our forest, not exploiting it, and from there we are planting more so the ones coming, the generations after us will also have a forest.

Practically all the people with whom there was interaction explained the importance of the interdependence between the community and the natural environment for their mutual well-being. Through this awareness, the need to renew collective knowledge is recognised. An employee of the communitarian forest company affirms that the village stands out because of its capacity for analysing and solving problems:

The community has always been distinguished because both comuneros and citizens learned from the elders, they were very protective of what we had. And the village is here thanks to that intention, that thinking of the elders, so the village would never falter, so that we could thrive.

From an educational code's perspective, history is an essential formative agent for these learnings, as are the historical actors - in other words, the ancestors who participated in decision-making processes and actions in defence of the territory. Traditionally, elders are important educational agents in the familial and social spheres.

As learners, we can identify the actors who lived or witnessed said events, their contemporaries, and their descendants, as well as the subsequent generations that have recognised the effects of these actions and motivations. A comunero says:

Despite its problems and setbacks, the village is like a home, it has had its ups and downs but it is still going. From everything we have lived through, we have learned and we have never stagnated in just one circle.

Some of the most relevant lessons are oriented towards endorsing the continuity of communitarian life and its values, as well as towards fostering an awareness of the fact that living generations are affected by the decisions and actions of their predecessors, and, accordingly, current actors should also be responsible for taking care of the natural heritage for those to follow.

In addition to the everyday practice of communality, some pedagogical resources include the social capacity for sharing opinions, debating and reaching agreement, for it is through these processes that learnings are shared, and meta-learnings can emerge when a meditative historical perspective is added. A vital pedagogical resource, as mentioned above, was the situation of crisis that triggered the plan of active resistance and the gathering of the necessary knowledge to do so. Necessity, interest, will, time and disposition are also added to the collection of social resources that enable these procedures.

These learnings are institutionalised and internalised in the current society. They are transformed into knowledge that is shared through social and familial pedagogies with new generations. In this way, they are established in the present life of the community and reproduced through community education. 
Figure 1. Commercial forestry activities in La Trinidad Ixtlán, Oaxaca. Photo: Jiangsu Olea.

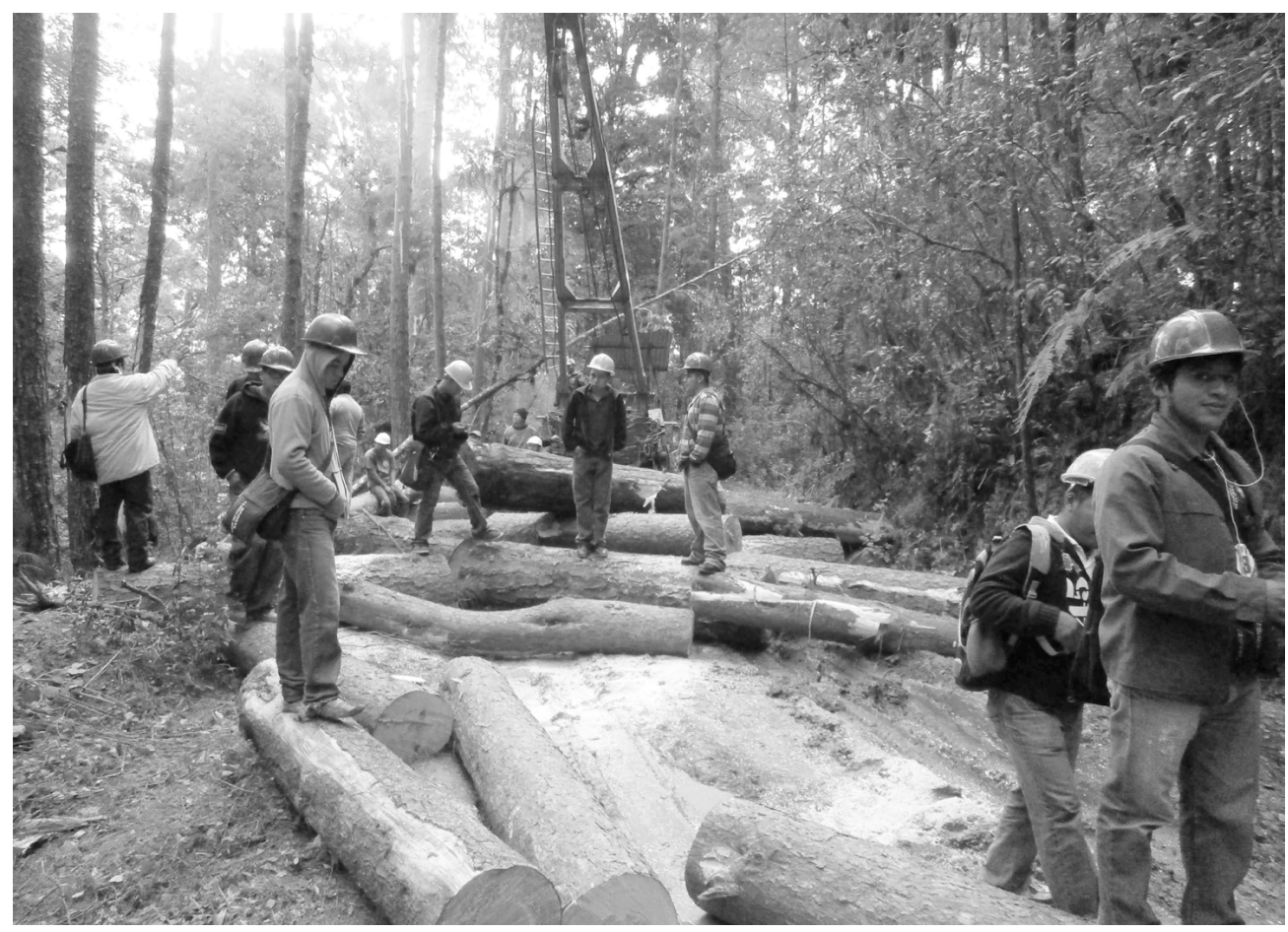

\section{Community education and social values}

As well as common ownership of the land, social organisation is vital for the historical continuity of La Trinidad Ixtlán. For such purposes, communitarian education constitutes an indispensable tool because it transmits the very knowledge and shared values that make historical continuity possible. Community life is in itself a permanent educative process in several areas, particularly in that of community service, one of the central axes of social organisation governed by the indigenous normative system.

The axis of the indigenous normative system is called the sistema de cargos (a system of key roles and duties), in which male citizens over 18 years of age are required to perform many communal and administrative roles (around 30), all without remuneration.

Most of the interviewees refer to their experience in the sistema de cargos as a school for the subjective learnings related to the life of the community, while others perceive the experience as one that creates good citizens. In other words, there is a conscious intention, or at least a precise sense of purpose, in the way in which community service prepares people for community life and the maintenance of collective good. An 82-year-old farmer says:

The community is wise. Most have already passed through all appointments, they know. There are rules: everyone in the community knows them. 
It is observed in this educational practice that the subject who learns is, in the first instance, the young citizen who joins the service, but also that same citizen further along the ladder of communitarian service, whereby, in a broader sense, this learner 'graduates' when he is 60 years old.

Because of the socialisation effects of this practice in the heart of the home, family units can be viewed as indirect apprentices. In other words, every situation or event related to the collective is shared with the whole community, either through formal channels or by the daily flow of communication into and among family groups. Intra-communitarian communication plays a relevant role in this circuit, where the community is itself an educative agent.

One of the main purposes of this educational practice is that the comunero experiences all positions of command (that is, community service), which imposes different perspectives on the subject, enriching his individual education and his journey as a citizen by providing him with learnings on community life. Through the experience of this service, the historical knowledge that shapes the current profile of the community is reaffirmed and critical thinking and decision-making capacities are generated. The comuneros learn to discern the importance of natural and social environmental knowledge and of transmitting these cultural values to the nuclear family, who, in turn, will incorporate them into their behaviour. Said values are condensed in the idea of communality: the solidarity, reciprocity, mutual care, service, respect, sharing, obedience and responsibility necessary for growing and living together.

The pedagogical strategies in this educative approach lie in the performance of the community, as the main teachers, in the act of serving: in the knowledge and responsibilities that correspond to a specific role in the sistema de cargos, and in the constant practice of reflection on, and analysis of, social events.

Here, even mistakes are seen as a form of learning. A comunero explains the role of mistakes in people's education:

The lesson that the elders gave us is that, if you make a mistake, you must not dwell on it, but improve yourself and make it better. I mean to focus on learning from our mistakes, be the best you can. Because those elders, if they made a mistake, they learned from it, and they did good things that taught us.

Other strategies include awareness raising, problematisation and the collective search for solutions, as well as the exchange of experiences and points of view with other community actors and external agents.

The location of this practice is community life. The temporal context exits in 1) the biographies of the individuals throughout their participation in the chain of communitarian appointments in the sistema; 2) the history of the community, through the training of its members in communitarian service and governing; and 3) in daily social or work interactions. This educational practice comprises wide spaces in the lives of community members, and frequently extends beyond the community as a result of the multiple actors interacting with $\mathrm{La}$ Trinidad because of its status as a model forest community. 


\section{Conclusions: Ontology as the basis for communitarian education}

The educational practices here described reveal the ontological principles that underlie the collective disposition of La Trinidad Ixtlán in maintaining a relationship of reciprocity with their natural environment and in maintaining a way of life that favours the common good.

From the present study, it can be concluded that one of the principles of such a disposition is the recognition of the community's direct dependence on the environment for biological subsistence, which in turn allows the social and cultural reproduction of the social fabric. Martínez (2015) affirms that when a society understands itself as part of nature, this appreciation enables life's reproduction and the creation of necessary knowledge, and strengthens the possibilities for the society's continuation.

A second principle is expressed in a subjective and inter-subjective awareness of belonging to the environment, as part of nature, which is then incorporated into notions of personal and cultural identity. This awareness is apparent in the community's bio-cultural identity.

The third principle is linked to the perception of time and involves taking care of 'the other' for mutual benefit, with the other including both humans and non-humans. This principle encompasses the continuity of life in all its expression, and is therefore of an evolutionary character.

This set of principles comprises the foundational purpose of this population, which is the possibility of existence, an ontological motivation fused with the environment. These principles are assimilated in the subject, the culture and in the community's store of collective knowledge, which is reproduced in every generation through the previously described educational practices. As a one of the comuneros says: 'From everything we have lived, we have learned'.

La Trinidad Ixtlán is an example of other possible ways that humans can relate to natural resources through ontological principles - principles that have materialised thanks to solid social organisation, a strict governance of the environment, and a great adaptability towards change. In the context of the aforementioned social practices, the community's capacity to recreate its learning strategies and store of knowledge (in order to successfully deal with the internal and external challenges posed by the historical, civilisational and environmental future) is very distinct. Following from this description, it is possible to view this population as an adaptive society (Ángel-Maya, 2003).

Although this study refers to a specific case, these approaches strengthen the argument that cultural and epistemic diversity offer an alternative to the current civilisational crisis that threatens, on a global scale, the conditions of life. Further, the research findings also highlight the importance of social educational processes in the development of sustainable societies. 


\section{Endnotes}

1. A holistic perspective evokes the concept of biocultural diversity. According to the National Commission for the Knowledge and Use of Biodiversity (Conabio, 2018), the biocultural axiom views biological and cultural diversity as mutually dependent and geographically tied. The biocultural relationship is thus a consequence of the interdependence between human societies and their biological surroundings.

2. Boege (2017) names as neo-indigenous those types of communities of indigenous heritage who have included elements of modern civilisation into their cultural tradition.

3. See Aparicio (2017).

4. Communality is defined by Martínez (2015) as an experiential concept that allows for the comprehensive, total, natural and communal understanding of life. Such a concept is based on four inseparable aspects: nature or the environment, the society or community that inhabit such a place, the work that is done by such a society, and what it receives for belonging to the social group and to the environment. This concept emerged as a social category in the region of the Sierra Norte of Oaxaca as part of the reflections developed during the fight against the forest concessions of the 1980s.

5. In the first case, once finalised, the ownership dispute with the municipal capital, Xiacuí, La Trinidad Ixtlán received a Presidential Resolution on the ownership of their lands in 1948. In the second case, the federal government gave the concession to a paper company to exploit, for 25 years, more than 260000 hectares of temperate forests in the region where La Trinidad is located (Winder, 1992). The concession expired in 1981, with plans for its renewal; however, the villages were able to prevent that.

6. Boege (2017) claims that reflections concerning the environment are triggered by a threat, causing a social movement that is usually reactive. He claims that crises permit the mobilisation of certain physical and symbolic elements of the communities, which are constantly reinventing themselves.

7. The concept of time in this community differs to the one of modern civilisation. Their perspective is not lineal or ephemeral, nor successive, but the past, present and future are rather perceived to operate simultaneously. This view is the legacy of the pre-Hispanic Mesoamerican cultures prevailing in their descendant populations: The Sacred Time (Boege, 2017). According to Eliade (1959), Sacred Time makes possible regular time, which is the ordinary passage of time in which all human existence goes by.

\section{Notes on the contributor}

Aparicio Cid, Raquel | UniversidadVeracruzana, Mexico | ORCID 0000-0003-0711-1769 | aparicio.cid@gmail.com

Raquel Aparicio Cid has a Phd in Educational Research and a Master's in Environmental Education. Her research interests are focused on environmental education, social educational practices, traditional knowledge systems, and human-environmental relations. 


\section{References}

Ángel-Maya, A. (2003). La diosa Némesis. Desarrollo sostenible o cambio cultural. Colombia: Corporación Universitaria Autónoma de Occidente.

Aparicio, R. (2017). La significación de la Naturaleza en los procesos formativos comunitarios. Los casos de Santiago Tilantongo y La Trinidad, Xiacuí, Oaxaca. Doctoral tesis, Instituto de Investigaciones en Educación, Universidad Veracruzana, México.

Barrera-Bassols, N. (2003). Symbolism, knowledge and management of soil and land resources in indigenous communities: Ethnopedology at global, regional and local scales, (Vol. I). Thesis submitted in the fulfillment of the requirements for the degree of Doctor $(\mathrm{PhD})$ in Earth Sciences, Ghent University, Enschede, The Netherlands: International Training Centre for PostGraduate Soil Scientists.

Boege, E. (2008). El patrimonio biocultural de los pueblos indigenas de México. México: INAH-CDI. Boege, E. (2017). Emeritus professor and researcher at the National Institute of Anthropology and History (INAH-México). Xalapa,Veracruz. 17 March 2017.

Chamoux, M.N. (1992). Trabajo, técnicas y aprendizaje en el México indígena. México: Centro de Investigaciones Superiores en Antropología Social-Centro de Estudios Mexicanos y Centroamericanos-Ediciones de la Casa Chata.

Conabio (Comisión Nacional para el Conocimiento y Uso de la Biodiversidad). (2018). Agrobiodiversidad. https://www.biodiversidad.gob.mx/biodiversidad/agrobiodiversidad.html

Díaz de Rada,Á. (2011). El taller del etnógrafo. Materiales y herramientas de investigación en etnografía. Madrid: UNED.

Eliade, M. (1959). The sacred and the profane. The nature of religion. (Transl. W.R. Trask). New York: Harvest Book Harcourt, Brace \& World, Inc.

Gómez, M. (2003). Saber indígena y medioambiente: experiencias de aprendizaje comunitario. In E. Leff (coord.), La complejidad ambiental (1st Ed., 2000) (pp. 253-291). México: Siglo XXI editores-PNUMA-UNAM.

Martínez, J. (2015). Conocimiento y comunalidad. Bajo el Volcán, 15(23), 99-112. Benemérita Universidad Autónoma de Puebla. Puebla, México.

Mignolo, W. (2014). Retos decoloniales, hoy. In M. Borsani y P. Quintero (comps.), Los desafíos decoloniales de nuestros días: pensar en colectivo (pp. 23-46). Neuquén, Argentina: EDUCOUniversidad Nacional del Comahue.

Milton, K. (1997). Ecologies: anthropology, culture and the environment. International Social Science Journal, 49(154), 477-495.

Nahmad, S. (1988). Tecnologías indígenas y medio ambiente. Análisis crítico de cinco regiones. México: Centro de Ecodesarrollo.

Olivé, L. (2009). Por una auténtica interculturalidad basada en el reconocimiento de la pluralidad epistemológica. In L. Olivé, B. Santos, C. Salazar, L. Antezana, W. Navia, L. Tapia, H. Suárez, Pluralismo epistemológico (pp. 19-30). La Paz: CLACSO-Muela del Diablo EditoresComunas-CIDES-UMSA.

Ornelas, A. (2007). Práctica educativa y formación de la personalidad. In R. Oscós (coord.), La práctica educativa desde la pedagogía social 1 (pp. 81-104). México: Primero Editores. 
Quijano, A. (2000). Colonialidad del poder, eurocentrismo y América Latina. In E. Lander (comp.), La colonialidad del saber: eurocentrismo y ciencias sociales (pp. 201-246). Perspectivas latinoamericanas. Buenos Aires: CLACSO.

Rengifo, G. (2015). Conocimiento previo, conocimiento otro. Desafíos del diálogo de saberes en las instituciones educativas rurales interculturales. Lima: Programa Andino de Tecnologías Campesinas (PRATEC).

Toledo, V.; Alarcón-Chaires, P.; Moguel, P.; Olivo, M.; Cabrera, A.; Leyequien, E. y RodríguezAldabe, A. (2002). Biodiversidad y pueblos indios en México y Centroamérica. Biodiversitas $43,1-8$.

Toledo, V. \& Barrera-Bassols, N. (2008). La memoria biocultural. La importancia ecológica de las sabidurías tradicionales. Barcelona: Icaria editorial.

Winder, D. (1992). De concesión maderera a comunidad forestal: cambio político, económico y social en la Sierra Juárez, Oaxaca. Lecture presented at the Seminario Latinoamericano in St. Antony's College. New York: The Synergos Institute. 